\title{
SERUM OSTEOPROTEGERIN IN PATIENTS WITH CALCIFIED AORTIC VALVE STENOSIS IN RELATION TO HEART FAILURE
}

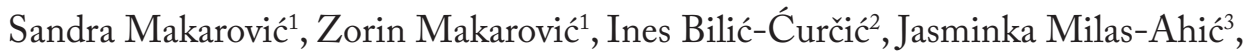 \\ Ivan Mihaljević ${ }^{4}$, Maja Franceschi ${ }^{5}$ and Tomislav Jukićs
}

${ }^{1}$ Clinical Department of Cardiovascular Disease, Osijek University Hospital Centre, School of Medicine, Josip Juraj Strossmayer University of Osijek, Osijek, Croatia; ${ }^{2}$ Clinical Department of Diabetes, Endocrinology and Metabolism Disorders, Osijek University Hospital Centre, School of Medicine, Josip Juraj Strossmayer University of Osijek, Osijek, Croatia; ${ }^{3}$ Clinical Department of Immunology and Allergology, Osijek University Hospital Centre, School of Medicine, Josip Juraj Strossmayer University of Osijek, Osijek, Croatia; ${ }^{4}$ Clinical Department of Nuclear Medicine and Radiation Protection, Osijek University Hospital Centre, School of Medicine, Josip Juraj Strossmayer University of Osijek, Osijek, Croatia; ${ }^{5}$ Department of Oncology and Nuclear Medicine, Sestre milosrdnice University Hospital Centre, School of Medicine, Josip Juraj Strossmayer University of Osijek, Osijek, Croatia

\begin{abstract}
SUMMARY - The aim of the study was to assess the role of serum osteoprotegerin (OPG) as a biomarker in patients with aortic valve stenosis (AS) in relation to heart failure and symptomatic status. This was a case control study, which included 51 patients with AS and 39 control subjects. At the time of study enrolment, detailed medical history was obtained and all subjects underwent physical examination, chest $\mathrm{x}$-ray and echocardiography. OPG levels were measured in all subjects, and serum $\mathrm{N}$-terminal of the pro b-type natriuretic peptide (NT pro BNP) levels were determined in patients with AS. Serum OPG levels were elevated in patients with AS compared to control subjects $(\mathrm{p}=0.001)$. Patients with heart failure due to AS had elevated serum OPG levels in comparison to patients without heart failure $(\mathrm{p}=0.001)$. A significant correlation between OPG and symptomatic status was observed in all patients with AS ( $\mathrm{p}<0.001)$, however, it was not the case in patients without heart failure $(\mathrm{p}=0.425)$. There was a positive correlation between OPG and NT pro BNP concentrations with objective signs of heart failure on chest $x$-ray $(p<0.001)$. Negative correlation of OPG concentrations with aortic valve area was present $(p<0.040)$, as well as with left ventricular ejection fraction ( $p<0.001$ ). Serum OPG could be a valuable biomarker in the evaluation of severity of calcified AS and serve as an additional indicator besides clinical presentation and echocardiography in the assessment of surgical treatment or aortic valve replacement.
\end{abstract}

Key words: Osteoprotegerin - blood; Aortic valve stenosis - pathology; Calcinosis - blood; Heart failure; Biomarkers - blood; Natriuretic peptides; Prognosis

\section{Introduction}

Calcified aortic valve stenosis (AS) is not just a degenerative process, as was previously thought. In the last decade, its inflammatory and atheromatous nature has been emphasized and it is considered a potentially modifying disease ${ }^{1,2}$. Calcified aortic valve disease is
Correspondence to: Sandra Makarovic, MD, Clinical Department of Cardiovascular Disease, Osijek University Hospital Centre, School of Medicine, Josip Juraj Strossmayer University of Osijek, J. Huttlera 4, HR-31000 Osijek, Croatia; E-mail: sandramakarovic@yahoo.com

Received March 21, 2017, accepted September 22, 2017 
the most common cause of aortic valve replacement in the western world, and increases in the prevalence with aging, affecting $2 \%-3 \%$ of the population by the age of 65 years $^{3}$.

Due to variability in the assessment of hemodynamic deterioration and difficulties in recognizing worsening of symptoms, the need for new serum biomarkers to assess the severity of AS has become an issue of utmost importance. In severe AS, the most studied biochemical marker is N-terminal of the pro b-type natriuretic peptide (NT pro BNP), which is the inactive fragment of $\mathrm{B}$-type natriuretic peptide (BNP) and is released from the myocardium in response to pressure and volume overload ${ }^{4-6}$. Clinical studies have shown that NT pro BNP has particular significance in determining the timing of surgery in asymptomatic patients with severe $\mathrm{AS}^{7}$, that symptomatic patients have a higher concentration of NT pro BNP than those without symptoms, and that asymptomatic patients who develop symptoms shortly after measuring NT pro BNP have a higher concentration than those that remain asymptomatic ${ }^{5,8}$.

Osteoprotegerin (OPG) and the OPG/RANKL/ RANK system are members of the tumor necrosis factor (TNF) receptor family ${ }^{9}$. They regulate the activity of osteoblasts and osteoclasts, and directly affect endothelial and vascular smooth muscle cells ${ }^{10-12}$. Inhibition of vascular calcification mediated through OPG in animal and in vitro studies ${ }^{13,14}$ has not been confirmed in clinical research ${ }^{15-17}$. Furthermore, numerous studies have demonstrated association of elevated OPG values and degenerative aortic valve disease ${ }^{18-21}$.

Therefore, it is conceivable that circulating levels of osteoprotegerin are increased in patients with severe calcified AS and in patients with heart failure as a complication of severe AS. Thus, OPG could represent a potential biomarker to determine optimal timing for surgical treatment in these patients and could provide relevant clinical information in addition to clinical presentation, NT pro BNP levels and echocardiography.

The aim of this study was to examine the value of OPG levels in relation to development of heart failure in patients with symptomatic severe AS, to characterize the association of OPG with left ventricular (LV) function and remodeling, and to determine the significance of serum OPG in asymptomatic patients with severe AS.

\section{Materials and Methods}

\section{Study design}

In this pair-matched case-control study, we compared a well-defined population of 51 patients with AS and preserved renal function but without coronary artery disease, ischemic cerebrovascular or peripheral vascular disease, and 39 control subjects without AS. The study participants were recruited from the population of patients hospitalized at the Department of Cardiology, Osijek University Hospital Center, for diagnostic evaluation of severe calcified AS.

This study complied with the Declaration of Helsinki and was approved by the Ethics Committee of the Osijek University Hospital Center. A written informed consent was obtained from each subject prior to inclusion in the study.

\section{Patient population}

The inclusion criteria for the study group included severe calcified aortic valve stenosis diagnosed by standard echocardiography. Severe AS was defined as the aortic valve area $<1 \mathrm{~cm}^{2}$ and mean systolic gradient $>50$ $\mathrm{mm} \mathrm{Hg}$. Left ventricular ejection fraction (LVEF) was also assessed according to European guidelines ${ }^{22}$, whereby patients with preserved systolic function had ejection fractions $\geq 50 \%$, and those with impaired systolic function had ejection fractions $<50 \%$. Control group subjects had no evidence of valvular disease, valve calcification, or coronary artery disease, as assessed by standard methods of echocardiography and exercise testing (by Bruce protocol).

Patients with a history of the following conditions were excluded from the study: previous myocardial infarction, coronary artery disease diagnosed with coronary angiography (presence of coronary artery stenosis $>50 \%$ ) or exercise testing, moderate and severe aortic and mitral valve insufficiency (defined by vena contracta $>0.3 \mathrm{~cm}$ ), history of coronary surgery, atrial fibrillation, macrovascular complications of diabetes, severe renal insufficiency (serum creatinine $>170$ $\mu \mathrm{mol} / \mathrm{L}$ ), severe ischemic peripheral vascular disease (patients with no concomitant leg symptoms), history of stroke, severe osteoporosis (on therapy), therapy with corticosteroids, immunosuppressive agents, hormone replacement therapy, and systemic diseases (history data). Exclusion criteria were identical for the study and control groups. 
Patients with aortic valve stenosis were further divided into three subgroups depending on the development of heart failure and symptoms: symptomatic AS and heart failure $(\mathrm{n}=29)$; symptomatic AS without heart failure $(\mathrm{n}=15)$; asymptomatic AS without heart failure $(n=14)$. Heart failure was diagnosed on clinical presentation according to NYHA classification, chest $\mathrm{x}$-ray (defined by the presence of redistribution on pulmonary vessels and broad vascular pedicle) and measurement of NT pro BNP serum levels (with cut-off level $>900 \mathrm{pg} / \mathrm{mL}$ for the diagnosis of heart failure).

All participants (patients and controls) were assessed for conventional cardiovascular risk factors, which were defined as follows: arterial hypertension: blood pressure $>140 / 90 \mathrm{~mm} \mathrm{Hg}$ or medically treated; hypercholesterolemia: serum cholesterol $>5.2 \mathrm{mmol} / \mathrm{L}$ or medically treated; diabetes mellitus: overnight fasting serum glucose $>7.0 \mathrm{mmol} / \mathrm{L}$ or medically treated; smoking history; positive family history of coronary artery disease; obesity: and body mass index (BMI) $>25 \mathrm{~kg} / \mathrm{m}^{2}$. Both groups, with and without AS, were age and gender matched and were closely aligned with respect to the risk factors which could otherwise alter serum OPG levels (Table 1 ).

Table 1. Baseline characteristics of study group (aortic stenosis) and control group

\begin{tabular}{|c|c|c|c|}
\hline & $\begin{array}{l}\text { Patients with } \\
\text { aortic stenosis } \\
(\mathrm{n}=51)\end{array}$ & $\begin{array}{l}\text { Control } \\
\text { subjects } \\
(\mathrm{n}=39)\end{array}$ & p value* \\
\hline Mean age (yrs) & 68.3725 & 66.7692 & $0.396^{\text {** }}$ \\
\hline $\begin{array}{l}\text { Gender: male } \\
\text { female }\end{array}$ & $\begin{array}{l}23 \\
28\end{array}$ & $\begin{array}{l}18 \\
21\end{array}$ & $0.922^{* *}$ \\
\hline $\begin{array}{l}\text { Arterial } \\
\text { hypertension }\end{array}$ & $41(80.4 \%)$ & $33(84.6 \%)$ & $0.417^{* *}$ \\
\hline Diabetes & $17(33.3 \%)$ & $14(35.9 \%)$ & $0.803^{* *}$ \\
\hline Hyperlipidemia & $42(82.4 \%)$ & $29(74.4 \%)$ & $0.372^{* *}$ \\
\hline Smoking status & $15(29.4 \%)$ & $13(33.3 \%)$ & $0.696^{* *}$ \\
\hline BMI & 28.3753 & 26.6500 & $1.000^{\text {**** }}$ \\
\hline
\end{tabular}

*Mann-Whitney U test; **Student's t-test; ${ }^{* * *} \chi^{2}$-test; BMI = body mass index

\section{Methods}

At the time of inclusion, detailed medical history was obtained and physical examination, electrocardiogram (ECG) and chest x-ray were performed. Patients with symptoms of severe AS and heart failure (breathlessness, intolerance effort, night cough, paroxysmal nocturnal dyspnea, hemoptysis), chest pain or syncope were classified as symptomatic, while asymptomatic patients were those with no symptoms whatsoever. $\mathrm{Pa}$ tients were then admitted to the Department of Cardiology, Osijek University Hospital Center for routine diagnostic preoperative work-up of severe calcified AS, which included coronary angiography and aortography. Thus, the presence of associated coronary artery disease was excluded (coronary artery disease was defined by the presence of coronary artery stenosis $>50 \%$ ).

Echocardiographic examination included transthoracic examination in both groups. Examinations were performed according to the European Society of Cardiology (ESC) guidelines, especially the European Association of Echocardiography/American Society of Echocardiography recommendations ${ }^{22}$. To evaluate AS, we measured maximum (AV Pg max) and mean (AV Pg mean) transvalvular pressure gradients, effective orifice area (EOA) using linear equation and aortic valve area (AVA) using planimetry. The parameters of left ventricular geometry, function and afterload were analyzed using standard methods. The parameters included left ventricular (LV) end-diastolic and end-systolic volume, LVEF, stroke volume, stroke volume index, interventricular septum, left ventricular mass, and left ventricular mass index. Left ventricular parameters were assessed using the two-dimensional left parasternal long axis view. Measurements were performed by two-dimensional ultrasound Siemens Acuson 70, with cardiac probe $\mathrm{P} 4-2$.

Peripheral venous blood samples of $10-12 \mathrm{~mL}$ were collected between 7 and 8.30 a.m., after at least 12hour fasting. Serum levels of glucose, creatinine, total cholesterol, high- and low-density lipoprotein cholesterol, and triglycerides were measured. Serum levels of OPG and NT pro BNP were measured with enzyme linked immunosorbent assays (Biomedica Medizinprodukte $\mathrm{GmbH} \&$ Co., Germany).

\section{Statistical analysis}

Results were analyzed using descriptive statistical analysis. Significance was declared at a two-sided 0.05 level, unless otherwise specified. Statistical analyses were performed using SPSS for Windows software (version 16.0, SPSS Inc., Chicago IL, USA). 
Difference between two independent variables was analyzed by Student's t-test for parametric analysis, while $\chi^{2}$-test and Mann-Whitney test were used for nonparametric analysis. Nonparametric analysis was used for smaller sample of examined variables, or, in our case, it was used for the analysis of serum OPG levels depending on the presence of heart failure. Nonparametric analysis was also used in the case of asymmetric distribution of the variables analyzed.

Normal distribution of numerical variables was tested by Kolmogorov-Smirnov test.

Spearman's correlation coefficients were computed to estimate the magnitude of the association between the variables of interest, in this case between serum OPG and NT pro BNP.

\section{Results}

\section{Serum OPG concentrations in patients with aortic stenosis and control group}

Table 2 shows serum OPG levels of pair-matched patients and controls. The mean value of serum OPG in patients with AS was significantly higher than in the control group $(6.54 \mathrm{pmol} / \mathrm{L}$ vs. $4.89 \mathrm{pmol} / \mathrm{L}$; $\mathrm{p}=0.001)$. Regarding cardiovascular risk factors, no statistically significant differences were recorded between these two groups (Table 1).

Table 2. Patients with aortic stenosis according to presence or absence of heart failure

\begin{tabular}{|l|l|l|l|}
\hline \multirow{2}{*}{ Group } & \multicolumn{2}{|l|}{$\begin{array}{l}\text { Serum concentration } \\
\text { of OPG }(\mathrm{pg} / \mathrm{mL})\end{array}$} & $\mathrm{p}^{*}$ \\
\cline { 2 - 4 } & Median & $25 \%-75 \%$ & \\
\hline Patients with AS & 6.54 & $4.90-9.32$ & $<0.001$ \\
$\begin{array}{l}\text { Control subjects } \\
\text { Aortic stenosis }\end{array}$ & 4.89 & $3.88-5.65$ & \\
patients: & & & \\
$\quad$ with heart failure & 9.78 & $7.55-11.34$ & $<0.001$ \\
without heart failure & 5.27 & $4.62-6.31$ & \\
\hline
\end{tabular}

AS = aortic stenosis; OPG = osteoprotegerin; ${ }^{*}$ Mann-Whitney U test

\section{Serum OPG concentrations in patients with $A S$ in relation to heart failure and serum NT pro BNP}

Within the study group (with AS), serum OPG levels were significantly elevated in patients with heart failure compared with serum OPG levels in the AS group without heart failure $(\mathrm{p}=0.001)$ (Table 2$)$. There was a strong positive correlation between $\mathrm{OPG}$ and NT-pro BNP levels in patients with AS $(\rho=0.796$, $\mathrm{p}<0.001$ ) (Table 3).

Table 3. Association of serum OPG concentration and NT pro BNP in patients with aortic stenosis and in patients with aortic stenosis in relation to chest $x$-ray

\begin{tabular}{|l|l|l|}
\hline Serum parameter & $\begin{array}{l}\text { Spearman correlation } \\
\text { coefficient }\end{array}$ & $\mathrm{p}$ \\
\hline OPG $(\mathrm{pg} / \mathrm{mL})$ & 0.796 & $<0.001$ \\
\hline NT pro BNP & 0.667 & $<0.001$ \\
\hline $\begin{array}{l}\text { Chest x-ray } \\
\text { Concentration } \\
\text { of OPG } \\
\text { Concentration } \\
\text { of NT pro BNP }\end{array}$ & 0.775 & $<0.001$ \\
\hline
\end{tabular}

$\mathrm{OPG}=$ osteoprotegerin; $\mathrm{NT}$ pro $\mathrm{BNP}=\mathrm{N}$-terminal brain natriuretic peptide

\section{Serum OPG concentrations in relation to symptomatic status of patients with aortic stenosis}

Patients with aortic valve stenosis were divided into three subgroups depending on the development of heart failure and symptoms: symptomatic AS and heart failure $(n=29)$; symptomatic AS without heart failure ( $\mathrm{n}=15)$; and asymptomatic AS without heart failure ( $n=14)$ (Table 4). A significant correlation be-

Table 4. Association of serum OPG concentration and symptomatic status in patients with aortic stenosis and serum $O P G$ concentration in $A S$ patients without heart failure in relation to symptomatic status

\begin{tabular}{|l|l|l|l|l|}
\hline $\begin{array}{l}\text { Patients with } \\
\text { aortic stenosis } \\
\text { (n=51) }\end{array}$ & $\mathrm{n}$ & \multicolumn{2}{|l|}{$\begin{array}{l}\text { Pearson correlation } \\
\text { coefficient }\end{array}$} & $\mathrm{p}$ \\
\hline $\begin{array}{l}\text { Symptomatic } \\
\text { status } \\
\text { Patients with AS } \\
\text { without heart } \\
\text { failure }\end{array}$ & 51 & 29 & $\begin{array}{l}\text { Serum OPG } \\
\text { concentration }\end{array}$ & $\mathrm{P}$ \\
\hline & 15 & Median & $25 \%-75 \%$ & $\mathbf{0 . 0 0 1}$ \\
\hline $\begin{array}{l}\text { Symptomatic } \\
\text { Asymptomatic }\end{array}$ & 14 & 4.94 & $4.62-6.31$ & $0.60-5.72$ \\
\hline
\end{tabular}

$\mathrm{AS}=$ aortic stenosis; $\mathrm{OPG}=$ osteoprotegerin 
tween serum concentrations of OPG and symptomatic status was observed in all patients with AS ( $\rho=-$ $0.554, \mathrm{p}<0.001$ ), however, there was no significant correlation of OPG concentration and symptomatic status in patients without heart failure $(\mathrm{p}=0.425)$ (Table 4). In addition, there was a positive correlation between serum concentrations of OPG and NT pro BNP with signs of heart failure on chest $x$-ray $(\rho=0.667, p<0.001$ and $\rho=0.775, p<0.001$, respectively) (Table 3 ).

\section{Serum OPG concentrations in relation to parameters of echocardiography (AVA, AV Pg mean, AVPg max, LVEF) in patients with aortic stenosis}

The relationship between OPG and parameters of echocardiography is shown in Table 5. A statistically significant negative relationship between serum concentrations of OPG and aortic valve area was observed $(\mathrm{r}=-0.321, \mathrm{p}<0.040)$. There was no correlation between serum OPG concentrations and medium or maximum aortic transvalvular pressure gradients. A negative correlation between serum OPG concentrations and LVEF $(\mathrm{r}=-0.571, \mathrm{p}<0.001)$ was recorded and serum OPG was elevated in patients with impaired LVEF $(\mathrm{EF}<50 \%)$.

Table 5. Analysis of OPG serum concentration in relation to parameters of echocardiography ( $A V A, A V P g$ mean, $A V P g$ max and LVEF) in patients with aortic stenosis

\begin{tabular}{|l|l|l|}
\hline $\begin{array}{l}\text { Osteoprotegerin concentration } \\
\text { Patients with AS }(\mathrm{n}=51)\end{array}$ & $\begin{array}{l}\text { Pearson } \\
\text { correlation } \\
\text { coefficient }\end{array}$ & $\mathrm{p}$ \\
\hline AVA $\left(<1 \mathrm{~cm}^{2}\right)$ & -0.321 & $\mathbf{0 . 0 4 0}$ \\
AV Pg mean $(50 \mathrm{~mm} \mathrm{Hg})$ & 0.189 & 0.317 \\
AV Pg max $(>80 \mathrm{~mm} \mathrm{Hg})$ & -0.004 & 0.976 \\
LVEF (cut-off value for reduced & -0.571 & $<\mathbf{0 . 0 0 1}$ \\
EF 50\%) & & \\
\hline
\end{tabular}

$\mathrm{AS}=$ aortic stenosis; $\mathrm{AVA}=$ aortic valve area $\mathrm{AV} \mathrm{Pg}$ mean = aortic valve transvalvular middle gradient; $\mathrm{AV} \mathrm{Pg} \max =$ aortic valve transvalvular maximum gradient; $\mathrm{LVEF}=$ left ventricular ejection fraction

$O P G$ in relation to heart failure in patients with aortic valve stenosis according to OPG values on $Y$-axis and presence or absence of heart failure on $X$-axis

The relationship between serum concentration of OPG and the presence or absence of heart failure is shown graphically on Boxplot analyses (Fig. 1). It is shown that OPG has significantly higher values in pa-

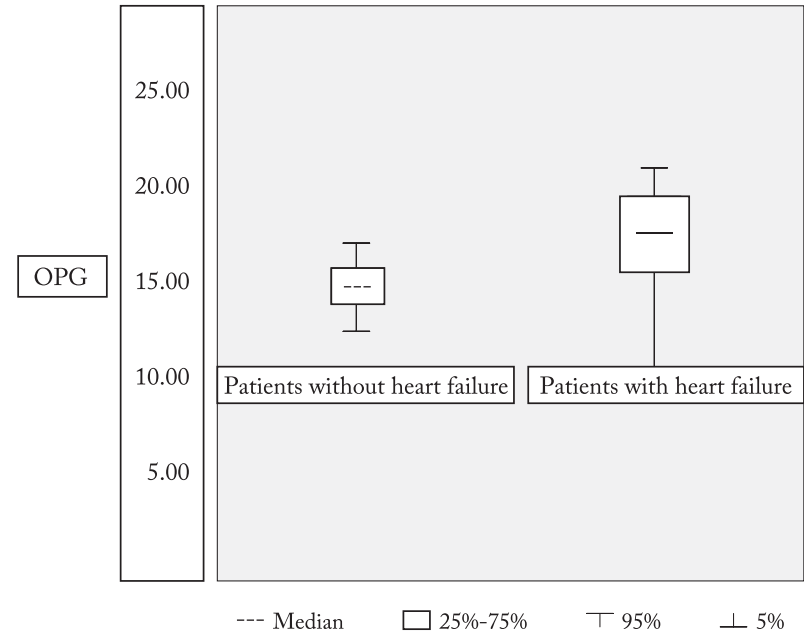

Fig. 1. Osteoprotegerin (OPG) level in relation to heart failure in patients with aortic valve stenosis, and presence or absence of heart failure.

tients with heart failure, when compared to patients without heart failure.

$O P G$ in relation to $L V E F$ in patients with aortic valve stenosis according to $O P G$ values on $Y$-axis and $L V E F$ $>50 \%$ and $<50 \%$ on $X$-axis

The relationship between serum concentration of OPG and LVEF $>50 \%$ or $<50 \%$ in patients with aortic valve stenosis is shown graphically on Boxplot analyses (Fig. 2). It is shown that OPG had significantly higher

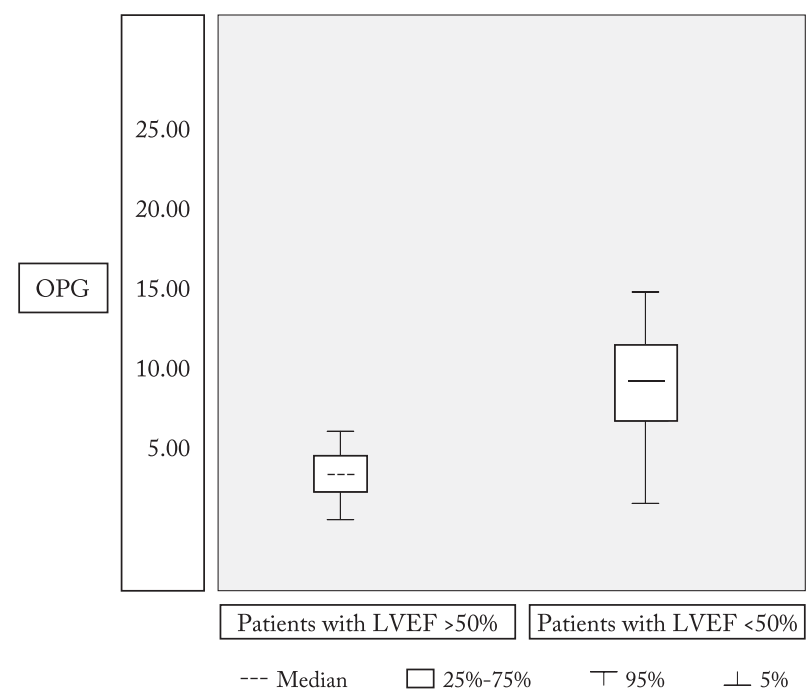

Fig. 2. Osteoprotegerin (OPG) level in relation to left ventricular ejection fraction (LVEF) in patients with aortic valve stenosis and $L V E F>50 \%$ or $L V E F<50 \%$. 
values in patients with $\mathrm{LVEF}<50 \%$ than in those with $\mathrm{LVEF}>50$.

\section{Discussion}

Early-stage degenerative aortic valve disease remains asymptomatic for many years, but when symptoms occur, the disease has often already progressed to severe stages ${ }^{4}$. With the occurrence of symptoms, 90\% of patients with untreated severe AS have a life expectancy of less than 10 years $^{23}$, and if AS is presenting with heart failure, the mortality is more than $50 \%$ within a year ${ }^{24}$. The purpose of biomarkers in AS is assessment of disease severity, thus allowing prognosis of disease outcome and potentially assisting in deciding on timely surgical procedure. Given the above, the objective of this study was to assess the value of serum OPG concentration as a biomarker in patients with calcified AS in relation to heart failure and symptoms.

In a study performed by Akat et al. ${ }^{21}$ elevated serum OPG concentrations were present in patients with calcified AS, however, patients with AS in this study were not divided into groups depending on the existence of heart failure. Our results not only revealed elevation of serum OPG concentrations in patients with calcified AS when compared to controls but also a statistically significant increase in serum OPG concentrations in patients with AS and heart failure compared to patients without heart failure. Previous reports investigated OPG levels in patients with ischemic and dilated cardiomyopathy and showed elevated serum levels in these patients ${ }^{25}{ }^{26}$, however, without reporting whether or not they developed heart failure. Unlike the former studies, our results showed elevation in serum concentrations of OPG in symptomatic patients with heart failure, and its increase with progression of NYHA stage, which could be a direct consequence of its increased myocardial release due to cardiac failure.

In all patients with AS, a significant correlation of OPG levels and symptomatic status was present, but no correlation was observed in the subgroup of $\mathrm{pa}^{-}$ tients without heart failure (both symptomatic and asymptomatic). This can be explained by the fact that patients with symptoms of dyspnea or heart failure had increased levels of OPG as a result of increased myocardial release, whereas in patients with other AS symptoms (angina and syncope) there were no signs of heart failure and therefore no significant differences in serum OPG concentrations were present. Also, the estimated severity of AS does not always correlate with the onset of symptoms and as a result, many patients with severe AS may be asymptomatic or in fact they do not recognize or choose to ignore their symptoms. Considering that those are high-risk patients and require close monitoring, it is difficult to assess the right time for surgical treatment. Presently, the recommendations for treating these patients, based on the ESC cardiac guidelines are in favor of conservative treatment and follow-up ${ }^{27}$. Therefore, serum OPG could be an additional marker for early screening of patients who need urgent aortic valve replacement, along with echocardiography monitoring, and already established elevated NT pro BNP levels.

A strong positive correlation of OPG and NT pro BNP exists in patients with heart failure due to $\mathrm{AS}^{28}$. This was also confirmed in our study, where a statistically significant positive correlation between serum OPG concentrations and NT pro BNP was observed in symptomatic patients with heart failure. Also, we established a positive correlation of serum OPG and NT pro BNP concentrations with the objective signs of heart failure present on chest x-ray. Apparently, elevated serum concentrations of both biomarkers of heart failure reflect objectively the state of lung congestion. Increase in these two biomarkers probably occurs as a result of different pathophysiological mechanisms that lead to heart failure. The fact that serum OPG is increased in patients with heart failure may be related to OPG as a predictor of increased cardiovascular mortality ${ }^{28,29}$.

Results on the correlation between serum OPG concentrations and AS severity in relation to the parameters of echocardiography are so far contradicto$\mathrm{ry}^{28,30,31}$. In our study, a negative correlation of serum OPG concentrations and AVA was observed, that is, a statistically significant increase in serum OPG concentrations was present in patients with smaller AVA. This could be explained by the presence of more severe calcifications in smaller AVA, and in that case, elevated serum OPG could be due to an anti calcified effect or compensatory mechanisms to limit the calcification process $^{32,33}$. There was no association of transvalvular gradients and OPG concentrations since our patients had impaired ejection fraction as opposed to previous studies where positive correlation of serum OPG levels and middle transvalvular gradient was present in 
patients with AS and preserved LV systolic function $^{30,31}$.

Our study results showed a strong negative correlation between LVEF and OPG concentrations, meaning that patients with worse ejection fraction had elevated OPG levels. This is consistent with previous studies, which demonstrated a significant negative correlation between serum concentrations of OPG and LVEF in the general population and in symptomatic patients with $\mathrm{AS}^{29,34}$.

This study had several limitations. It was a crosssectional study, so we could not establish causal relationship, and the number of patients was relatively small. Furthermore, there are some issues in using OPG as a biomarker in patients with calcified AS that need to be addressed. The presence of severe renal failure $^{36}$, acute exacerbation of coronary disease ${ }^{37}$, severity of coronary artery disease on angiography ${ }^{38}$ and other causes of heart failure ${ }^{17}$ could conceal the real cause of elevated serum OPG concentrations. However, in all of these patients, there is a positive correlation between serum OPG and total cardiovascular disease mortality ${ }^{28,29}$. Presently, there is no exact reference value when OPG is considered significantly elevated indicating a worse prognostic outcome, but we demonstrated that its serum concentration increased with the degree of heart failure defined according to NYHA stage and correlated positively with the NT pro BNP biomarker, which is considered a good indicator of the status of symptomatic $\mathrm{AS}^{6}$.

\section{Conclusion}

In conclusion, elevated serum OPG levels are associated with the existence of calcification and stenosis of the aortic valve, and with the development of heart failure in patients with severe calcified AS. Thus, it would be possible to use serum OPG in the evaluation of severity of calcified AS, and as an auxiliary indicator in the assessment of surgical treatment or aortic valve replacement in addition to clinical presentation and echocardiography.

\section{References}

1. Freeman RV, Otto CM. Spectrum of calcific aortic valve disease: pathogenesis, disease progression, and treatment strategies. Circulation. 2005;21:3316-26.

DOI: 10.1161/CIRCULATIONAHA.104.486738.
2. Rajamannan NM. Calcific aortic stenosis: lessons learned from experimental and clinical studies. Arterioscler Thromb Vasc Biol. 2009;29:162-8. DOI: 10.1161/ATVBAHA.107.156752.

3. Otto CM, Lind BK, Kitzman DW, Gersh BJ, Siscovick DS. Association of aortic-valve sclerosis with cardiovascular mortality and morbidity in the elderly. N Engl J Med. 1999;15: 142-7. DOI:10.1056/NEJM199907153410302.

4. Braunwald E, Bonow RO, Mann DL, Zipes DP, Libby P. Valvular heart disease. In: Braunwald E, editor. Braunwald's Heart Disease. A Textbook of Cardiovascular Medicine. Boston, MA: Elsevier Saunders, 2011; p 1468-78.

5. Carabello BA, Paulus W. Aortic stenosis. Lancet 2009;373: 956-66. DOI: 10.1016/S0140-6736(09)60211-7.

6. Weber M, Hausen M, Arnold R, Nef H, Moellman H, Berkowitsch A, Elsaesser A, et al. Prognostic value of N-terminal pro-B-type natriuretic peptide for conservatively and surgically treated patients with aortic valve stenosis. Heart. 2006; 92:1639-64. DOI: 10.1136/hrt.2005.085506.

7. Sattler A, Schoppet M, Schaefer J, Hofbauer L. Novel aspects on RANK ligand and osteoprotegerin in osteoporosis and vascular disease. Calcif Tiss Int. 2004;74:103-6.

DOI: $10.4103 / 0366-6999.185857$.

8. Potočnjak I, Bodrožić-Džakić T, Šmit I, Trbušić M, Milošević M, Degoricija V. Gender-associated differences in acute heart failure patients presenting to emergency department. Acta Clin Croat. 2015;54:257-65.

9. Hofbauer LC, Schoppet M. Clinical implications of the osteoprotegerin/ RANKL/RANK system for bone and vascular diseases. JAMA. 2004;292:490-5.

DOI: 10.1001/JAMA.292.4.490.

10. Doherty TM, Asotra K, Fitzpatrick LA, Qiao JH, Wilkin DJ, Detrano RC, et al. Calcification in atherosclerosis: bone biology and chronic inflammation at the arterial crossroads. Proc Natl Acad Sci U S A. 2003;100:11202-6. DOI: $10.1073 /$ pnas.1932554100.

11. Schoppet M, Preissner KT, Hofbauer LC. RANK ligand and osteoprotegerin: paracrine regulators of bone metabolism and vascular function. Arterioscler Thromb Vasc Biol. 2002;22: 549-53.

12. Collin Osdoby P. Regulation of vascular calcification by osteoclast regulatory factors RANKL and osteoprotegerin. Circ Res. 2004;95:1046-57.

DOI: 10.1161/01.RES.0000149165.99974.12.

13. Bennett BJ, Scatena M, Kirk EA, Rattazzi M, Varon RM, Averill M, Schwartz SM, et al. Osteoprotegerin inactivation accelerates advanced atherosclerotic lesion progression and calcification in older APO E-/- mice. Arterioscler Thromb Vasc Biol. 2006;26:2117-24.

DOI: 10.1161/01.ATV.0000236428.91125.e6.

14. Min H, Morony S, Sarosi I, Dunstan CR, Capparelli C, Scully $\mathrm{S}$, Van $\mathrm{G}$, et al. Osteoprotegerin reverses osteoporosis by inhibiting endosteal osteoclasts and prevents vascular calcification by blocking a process resembling osteoclastogenesis. J Exp Med. 2000;192:463-74. 
15. Nybo M, Rasmussen LM. The capability of plasma osteoprotegerin as a predictor of cardiovascular disease: a systematic literature review. Eur J Endocrinol. 2008;159:603-8. DOI: 10.1530/EJE.08.0554.

16. Jono S, Ikari Y, Shioi A, Mori K, Miki T, Hara K. Serum osteoprotegerin levels are associated with the presence and severity of coronary artery disease. Circulation. 2002;106:1192-4. DOI: 10.1111/j.1538-7836.2010.03833.x.

17. Ueland T, Jemtland R, Godang K, Kjekshus J, Hognestad A, Omland T. Prognostic value of osteoprotegerin in heart failure after acute myocardial infarction. Am J Coll Cardiol. 2004; 44:1970-6. DOI: 10.1371/JOURNAL.PONE.0160182.

18. Rajamannan NM, Otto CM. Targeted therapy to prevent progression of calcific aortic stenosis. Circulation. 2004;110: 1180-2. DOI: 10.1161/01.CIR.0000140722.85490.EA.

19. Helske S, Kupari M, Lindstedt KA, Kovanen PT. Aortic valve stenosis: an active atheroinflammatory process. Curr Opin Lipidol. 2007;18:483-91.

DOI:10.1097/MOL.0b013e3282a66099.

20. Kaden JJ, Dempfle C-E, Grobholz R, Fischer CS, Vocke DC, Kiliç R, et al. Inflammatory regulation of extracellular matrix remodeling in calcific aortic valve stenosis. Cardiovasc Pathol. 2005;14:80-6. DOI: 10.1016/J.CARPATH.2005.01.002

21. Akat K, Kaden JJ, Schmitz F, Ewering S, Anton A, Klomfab S. Calcium metabolism in adults with severe aortic valve stenosis and preserved renal function. Am J Cardiol. 2010;105:862-4. DOI: 10.1016/J.AMJCARD.2004.07.095.

22. Baumgartner H, Hung J, Bermejo J, Chambers JB, Evangelista A, Griffin BP, et al.; American Society of Echocardiography; European Association of Echocardiography. Echocardiographic assessment of valve stenosis: EAE/ASE recommendations for clinical practice. J Am Soc Echocardiogr. 2009;22:1-23. DOI: 10.1016/J.ECHO.2008.11.029.

23. Rajamannan NM, Bonow RO, Rahimtoola SH. Calcific aortic stenosis: an update. Nat Clin Pract Cardiovasc Med. 2007; 4:254-62. DOI: 10.1038/NCPCARDIO0827.

24. Frank S, Johnson A, Ross J Jr. Natural history of valvular aortic stenosis. Br Heart J. 1973;35:41-6.

25. Ueland T, Yndestad A, Øie E, Florholmen G, Halvorsen B, Frøland SS, et al. Dysregulated osteoprotegerin/RANK ligand/ RANK axis in clinical and experimental heart failure. Circulation. 2005;111:2461-8. DOI: 10.1161/01.CIR.0000165119.62099.14.

26. Schoppet M, Ruppert V, Hofbauer LC, Henser S, Al-Fakhri $\mathrm{N}$, Christ M, et al. TNF-related apoptosis-inducing ligand and its decoy receptor osteoprotegerin in nonischemic dilated cardiomyopathy. Biochem Biophys Res Commun. 2005;30: 1745-50. DOI: 10.1093/RHEUMATOLOGY/KEL108.

27. Vahanian A, Alfieri O, Andreotti F, Antunes MJ, Baron-Esquivias G, Baumgartner H, et al.; Joint Task Force on the Management of Valvular Heart Disease of the European Society of Cardiology (ESC) and the European Association for CardioThoracic Surgery (EACTS). Guidelines on the management of valvular heart disease (version 2012): the Joint Task Force on the Management of Valvular Heart Disease of the European Society of Cardiology (ESC) and the European Association for Cardio-Thoracic Surgery (EACTS). Eur J Cardiothorac Surg. 2012;42(4):S1-44. DOI: 10.1093/EURHEARTJ/EHS109.

28. Ueland T, Aukrust P, Dahl CP, Husebye T, Solberg OG, Tønnessen $\mathrm{T}$, et al. Osteoprotegerin levels predict mortality in patients with symptomatic aortic stenosis. J Intern Med. 2011; 270(5):452-60. DOI: 10.1111/j.1365-2796.2011.02393.x.

29. Dahl JS, Videbæk L, Poulsen MK, Rudbaek TR, Christensen NL, Pellikka PA, et al. Relation of osteoprotegerin in severe aortic valve stenosis to postoperative outcome and left ventricular function. Am J Cardiol. 2013;112(9):1433-8. DOI: 10.1161/CIRCIMAGING.112.973834.

30. Borowiec A, Dąbrowski R, Kowalik I, Firek B, Chwyczko T, Janas J, et al. Osteoprotegerin in patients with degenerative aortic stenosis and preserved left-ventricular ejection fraction. J Cardiovasc Med. 2015 Jun;16(6):444-50. DOI: 10.2459/JCM.0000000000000035.

31. Borowiec A, Dabrowski R, Janas J, Firek B, Kowalik I, SmolisBak E, et al. Role of osteoprotegerin and other markers of atherosclerosis in patients with calcific aortic stenosis. Eur J Echocardiogr. 2010;11(2):51.

32. Van Campenhout A, Golledge J. Osteoprotegerin, vascular calcification and atherosclerosis. Atherosclesosis. 2009;204:321-9. DOI: 10.1016/J.ATHEROSCLEROSIS.2008.09.033.

33. Hofbauer LC, Schoppet M. Clinical implications of the osteoprotegerin/RANKL/RANK system for bone and vascular diseases. JAMA. 2004;292(4):490-5. DOI:10.1001/JAMA.292.4.490.

34. Omland T, Drazner MH, Ueland T, Abedin M, Murphy SA, Aukrust $\mathrm{P}$, et al. Plasma osteoprotegerin levels in the general population: relation to indices of left ventricular structure and function. Hypertension. 2007;49(6):1392-8. DOI:10.1161/HYPERTENSIONAHA.107.087742.

35. Helske S, Kovanen PT, Lindstedt KA, Salmela K, Lommi J, Turto H, Werkkala K, et al. Increased circulating concentrations and augmented myocardial extraction of osteoprotegerin in heart failure due to left ventricular pressure overload. Eur J Heart Fail. 2007;9:357-63. DOI: 10.1016/J.EJHEART.2006.10.015.

36. Kazama JJ. Osteoprotegerin and bone mineral metabolism in renal failure. Curr Opin Nephrol Hypertens. 2004;13(4):411-5. DOI: $10.3390 / N U 5061913$

37. Omland T, Ueland T, Jansson AM, Persson A, Karlsson T, Smith C, et al. Circulating osteoprotegerin levels and longterm prognosis in patients with acute coronary syndrome. J Am Coll Cardiol. 2008;51:627-33. DOI: 10.1016.J.JACC.2007.09.058.

38. Rhee EJ, Lee WY, Kim SY, Kim BJ, Sung KC, Kim BS. Relationship of serum osteoprotegerin levels with coronary artery disease severity, left ventricular hypertrophy and C-reactive protein. Clin Sci. 2005;108:237-43.

DOI: 10.1097/QAI.0000000000000725. 


\section{Sažetak \\ SERUMSKA VRIJEDNOST OSTEOPROTEGERINA U BOLESNIKA S KALCIFICIRAJUĆOM AORTNOM STENOZOM U OVISNOSTI O ZATAJENJU SRCA}

\section{S. Makarović, Z. Makarović, I. Bilić-Ćurčić, J. Milas-Ahić, I. Mihaljević, M. Franceschi i T. Jukić}

Cilj ove studije bio je ocijeniti ulogu osteoprotegerina (OPG) kao biljega u bolesnika sa stenozom aortnog srčanog zaliska u odnosu na prisutne simptome kao i stupanj srčanog zatajenja. U studiju je bio uključen 51 bolesnik s aortnom stenozom (AS) i 39 kontrolnih ispitanika. Prije uključenja u studiju uzeta je detaljna anamneza, učinjen je fizikalni pregled, rentgenska snimka srca i pluća te ehokardiografija. OPG je određen u svih ispitanika, a N-terminalni nastavak pro b-tipa natriuretskog peptida (NT pro BNP) bio je određen u bolesnika s AS. OPG je bio povišen u bolesnika s AS u odnosu na kontrolne ispitanike $(p=0,001)$. Bolesnici sa srčanim zatajenjem zbog AS imali su povišene razine OPG-a u odnosu na bolesnike bez srčanog zatajenja ( $p=0,001)$. Značajna korelacija između OPG-a i simptomatskog statusa bila je zapažena u svih bolesnika s AS $(\mathrm{p}<0,001)$, ali to nije bio slučaj u bolesnika bez srčanog zatajenja ( $\mathrm{p}=0.425)$. Zabilježena je i pozitivna korelacija između koncentracije OPG-a i NT pro BNP-a s objektivnim znakovima srčanog zatajenja na rentgenskoj snimci srca i pluća $(\mathrm{p}<0,001)$. Također je opažena negativna korelacija OPG-a i areje aortnog zaliska $(\mathrm{p}<0,040)$ te istisne frakcije lijeve klijetke ( $\mathrm{p}<0,001)$. OPG bi mogao predstavljati vrijedan biljeg u procjeni težine kalcificirane AS te bi mogao poslužiti kao dodatni indikator prilikom odlučivanja o kirurškom liječenju ili zamjeni aortnog zaliska, naravno, uz kliničku prezentaciju i ehokardiografiju.

Ključne riječi: Osteoprotegerin-krv; Aortni srčani zalistak, stenoza-patologija; Kalcinoza-krv; Srčano zatajivanje; Biomarkeri-krv; Natriureticni peptidi; Prognoza 